\title{
The Effect of Integrated Safety Intervention Practices on Applicant Safety Behavior at PT Esa Bumindo
}

\author{
Asep Abdurahman Tsani, Jeremy Rizky Marchziany, Yudhistira Dwi Hapsara, Sambudi Hamali
}

\begin{abstract}
The purpose of this study was to determine the effect of management safety interventions, human safety interventions, technical safety interventions on safety behavior. The research method used is a quantitative method, with the type of causal research. Data collection was done by distributing questionnaires to all employees of PT. Esa Bumindo a total of 50 people. Data analysis method using SEM-PLS with WarpPLS 6.0 software. The results obtained from this study are management interventions affecting technical safety interventions, human safety interventions, and safety behaviors. Human safety interventions affect technical safety interventions and safety behavior. Technical safety interventions affect safety behavior. The results of this study indicate that to improve safety behavior, managers must improve management, human, and technical safety interventions.
\end{abstract}

Keywords: Management Safety Interventions, Technical Safety Interventions, Human Safety Interventions, Safety Behavior.

\section{INTRODUCTION}

$\mathrm{O}$ chemical industry are still wide open in the future. With a population of around 230 million souls and the availability of abundant natural resources, Indonesia has the opportunity to put themselves at the forefront of the development of the chemical industry. The Director delivered it of Upstream Chemical Industry Ministry of Industry, Muhammad Khayam at the opening of the Exhibition International Chemical Summit and Exhibition (InaChem 2016) and Indonesia Building Mechanical \& Electrical Expo 2016 in Jakarta. Human life is inseparable from the use of chemicals produced by the chemical industry. Therefore, the production and consumption of chemical products often used as a measure of the level of progress and welfare of a

Revised Manuscript Received on July 10, 2020

* Correspondence Author

Asep Abdurahman Tsani, Management Department, BINUS Business School Undergraduate Program, Bina Nusantara University, Jakarta, Indonesia.

Jeremy Rizky Marchziany, Management Department, BINUS Business School Undergraduate Program, Bina Nusantara University, Jakarta, Indonesia.

Yudhistira Dwi Hapsara, Management Department, BINUS Business School Undergraduate Program, Bina Nusantara University, Jakarta, Indonesia.

Sambudi Hamali*, Management Department, BINUS Business School Undergraduate Program, Bina Nusantara University, Jakarta, Indonesia. E-mail: sambudi_hamali@binus.ac.id

(c) The Authors. Published by Blue Eyes Intelligence Engineering and Sciences Publication (BEIESP). This is an open access article under the CC BY-NC-ND license (http://creativecommons.org/licenses/by-nc-nd/4.0/) pportunities for the development of the national

country. The chemical industry value chain is closely related to the productive economic sector, namely food, clothing, and housing, as well as the supply of raw materials for various downstream industries including the electronics and automotive industries. Various chemical industries have developed in Indonesia, among them are the petrochemical, oleochemical, agrochemical, and so on industries. The chemical industry also produces various chemical products to meet the needs and improve the living standards of the Indonesian people. [1]. PT. Esa Bumindo is a company engaged in the field of adhesives (glue), which located at Jalan Raya Pasar Kemis, Tangerang Regency. At present, the company is developing its business in the field of sanitation materials, such as dishwashing liquid, clothes softener, floor cleaner, fragrant carbolic acid, and detergent powder. Based on interviews with the Human Resources Manager, PT.Esa Bumindo was already implementing K3 (Healthy and Safety ), but still an accident at companies such. Accident prevention and prevention has done spontaneously, and there are no standard operating procedures, for example, there have been several work accidents on employees that are exposed to a drum cap that causes injury to the elbow. Other accidents such as itching on the hands after being exposed to chemicals, and in specific processes can cause the hands and faces of workers to be exposed to chemicals.

Table- I: List of Accident Rates at PT Esa Bumindo Year 2017

\begin{tabular}{|c|c|c|c|c|}
\hline \multirow{2}{*}{ No. } & \multirow{2}{*}{ Month } & \multicolumn{3}{|c|}{ Information } \\
\cline { 3 - 5 } & & $\begin{array}{c}\text { The } \\
\text { wound } \\
\text { chemicalled }\end{array}$ & $\begin{array}{c}\text { Limbs } \\
\text { exposed } \\
\text { to } \\
\text { chemicals }\end{array}$ \\
\hline 1 & Mar-17 & - & 5 & 2 \\
\hline 2 & Apr-17 & 2 & 8 & 3 \\
\hline 3 & May-17 & - & 6 & 2 \\
\hline 4 & Jun-17 & 1 & 7 & 1 \\
\hline 5 & Jul-17 & - & 10 & 4 \\
\hline 6 & Aug-17 & - & 6 & 3 \\
\hline 7 & Sep-17 & 2 & 8 & 2 \\
\hline 8 & Oct-17 & - & 7 & 2 \\
\hline 9 & Nov-17 & - & 8 & 6 \\
\hline 10 & Dec-17 & 3 & 10 & 4 \\
\hline 11 & Jan-18 & - & 12 & 3 \\
\hline
\end{tabular}




\begin{tabular}{|c|c|c|c|c|}
12 & Feb-18 & - & 9 & 5 \\
\hline & Total & 8 & 96 & 37 \\
\hline
\end{tabular}

Source: PT. Esa Bumindo, 2018

According to [2], work safety behavior is influence by integrated safety intervention practices, the dimensions of integrated safety intervention practices are management safety interventions, human safety interventions, and technical safety interventions. Based on this research, the causes of workplace accidents at PT. Esa Bumindo allegedly influenced by the lack of integrated safety intervention practices in the company.

Based on previous research conducted by Wang, Zou, and Li (2015) in the construction industry in China, where the problem faced is the fatal accidents that occurred around 20\% - 40\% in 2014. This study uses the Confirmatory Factor Analysis (CFA ) method ) and Structural Equation Modeling (SEM). Their results showed that human safety interventions had a positive effect on safety behavior.

Other previous research conducted by [3] nuclear power plants in Europe, where the problem faced is that there are 60 nuclear power plants that are under construction, which can cause widespread fatal disasters in the nearby region. This study uses the Confirmatory Factor Analysis (CFA) method and uses LISREL 8.8 software. Their results show that management safety interventions affect safety behavior.

The difference between this research and previous research is a different unit of analysis, namely in the chemical industry, while previous studies in the construction industry and nuclear power generation.

Based on the above, the formulation of the problem in this study is whether the intervention Safety Risk Management effect on intervention technical safety, if safety interventions management affects the safety interventions of man, whether safety interventions management directly affects the safety behavior, whether the intervention of the safety of human influence on technical intervention safety, does human safety intervention affect safety behavior, does technical safety intervention affect safety behavior.

While the purpose of this study is to determine the effect of management safety interventions on technical safety interventions, to determine the effect of management safety interventions on human safety interventions, to determine the effect of management safety interventions on safety behavior, to determine the effect of human safety interventions on technical safety interventions, to know the effect of human safety interventions on safety behavior, to determine the effect of technical safety interventions on safety behavior.

Several previous studies discussing work safety behavior, including [2], showing the positive influence of Safety Interventions on Human Safety Interventions; the positive influence of Management Safety Interventions on Technical Safety Interventions; the positive influence of Human Safety Interventions on Technical Safety Interventions; the absence of the influence of Management Safety Interventions on Safety Behavior; no influence on Safety Behavior; Technical Safety Interventions have a positive effect on Safety Behavior. [3] research results show the influence of safety management interventions on safety behavior. While the results of Wang, Zou, and Li's (2015) research, show that human safety interventions have a positive effect on safety behavior. Based on research by [2], the following research hypotheses are arranged :

H1: Effect of management safety interventions on interventions human safety.

$\mathrm{H} 2$ : Effect of management safety interventions on interventions technical safety.

H3: Effects of human safety interventions on interventions technical safety.

H4: Effect of management safety interventions on behavior safety.

H5: Effect of human safety interventions on behavior safety. H6: Effect of technical safety interventions on safety behavior.

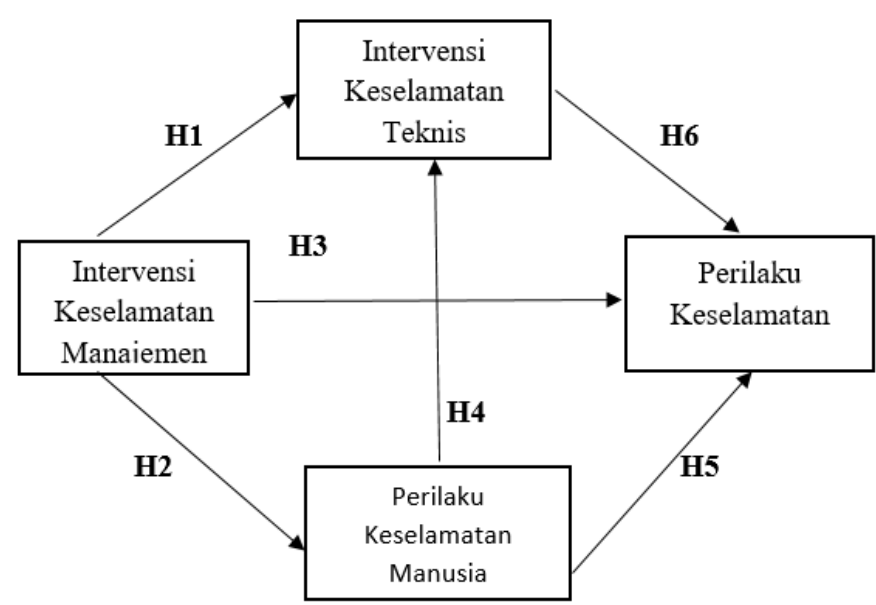

Fig. 1. Research Model

\section{RESEARCH METHOD}

The research method used in this study is quantitative. According to [4], the quantitative research method is a research method based on empirical evidence to investigate social phenomena through statistical principles. The purpose of quantitative research methods is to obtain mathematical patterns or models, theoretical proofs, and hypotheses formed by researchers. The measurement process is critical in quantitative research methods because it is a bridge between empirical observations and mathematical expressions of quantitative relationships. This type of research is causal research. According to [5], causal research is a type of research designed to collaborate on one or more of several problems. This research will explain that variable $\mathrm{X}$ is the cause of variable $Y$. This study also examines the relationship between variables. The unit of analysis in this organizational research is PT. Esa Bumindo. The time horizon in this study is cross-sectional, according to [5], cross-sectional is a study in which data is only collected once to answer research questions. In this study, the type of data used is quantitative data. Quantitative data is information data in the form of numbers or numbers symbols. Based on the symbols of the numbers, quantitative calculations can be carried out to produce a generally accepted conclusion within a parameter (Maulidi, 2016). The data source used in this study is primary data, that is data provided directly to data collectors (Sugiyono, 2014).

\section{Published By:}

Blue Eyes Intelligence Engineering \& Sciences Publication

(C) Copyright: All rights reserved.

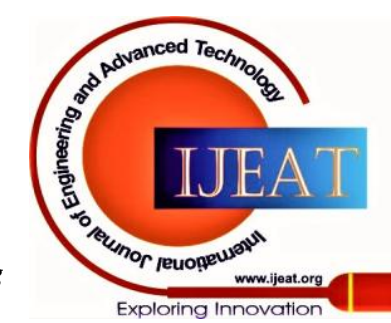


The primary data used is sourced from the results of a questionnaire filled out by employees of PT. Esa Bumindo. Data collection techniques in this study used a questionnaire and also used the saturation sampling technique as a technique for determining the sample.

This research uses WarpPLS 6.0 software. WarpPLS 6.0 is an application program (software) with partial least square, which is a non-linear analysis method and is not based on many assumptions (Kock, 2017).

\section{RESULT AND DISCUSSION}

Data analysis method in this study was conducted using SEM-PLS with WarpPLS 6.0 software. WarpPLS program can identify nonlinear relationships between the variables of latent and correcting coefficient based on the path right of the relationship. Therefore, the program is named Warp, which means arch. Kock (2010) in [6], states that WarpPLS is the first software that can do that.

\section{A. Evaluation of the Outer Model}

Convergent validity is related to the principle that the manifest variables of a construct should be highly correlated. Test the convergent indicator convergence validity with SmartPLS can be seen with the loading factor value for each construct indicator. The rule of thumb used to assess convergent validity is that the loading factor value must be more than 0.7 for confirmatory research and loading factor values between 0.6-0.7 for explanatory research, and the average variance extracted (AVE) value must be greater than 0.5 (Campbell and Fiske 1959) in Ghozali (2012).

Table- II: Cross Loading

\begin{tabular}{|l|l|l|l|}
\hline Variable & Indicator & Loading & P value \\
\hline Where & Mana1 & 0.646 & $<0.001$ \\
& Mana2 & 0.726 & $<0.001$ \\
& Mana3 & 0710 & $<0.001$ \\
& Mana4 & 0.748 & $<0.001$ \\
& Mana5 & 0.658 & $<0.001$ \\
& Mana6 & 0.626 & $<0.001$ \\
\hline Tech & Tek1 & 0740 & $<0.001$ \\
& Tek2 & 0795 & $<0.001$ \\
& Tek3 & 0.696 & $<0.001$ \\
& Tek4 & 0712 & $<0.001$ \\
& Tek5 & 0.619 & $<0.001$ \\
& Tek6 & 0821 & $<0.001$ \\
& Tek7 & 0819 & $<0.001$ \\
\hline \multirow{5}{*}{ Manu } & Manu1 & 0.634 & $<0.001$ \\
& Manu2 & 0.689 & $<0.001$ \\
& Manu3 & 0.771 & $<0.001$ \\
& Manu4 & 0728 & $<0.001$ \\
& Manu5 & 0.721 & $<0.001$ \\
& Manu6 & 0.680 & $<0.001$ \\
\hline \multirow{5}{*}{ PK } & PK1 & 0780 & $<0.001$ \\
& PK2 & 0.939 & $<0.001$ \\
& PK3 & 0.920 & $<0.001$ \\
& PK4 & 0.960 & $<0.001$ \\
& PK5 & 0.656 & $<0.001$ \\
& PK6 & 0.916 & $<0.001$ \\
\hline
\end{tabular}

Source: Data Processing Results, 2018

Convergent validity according to (Hair et al., 2013), in Solihin and Ratmono (2013), the convergent validity

requirement for reflective constructs namely outer loading must be above 0.70 and $p$ is significant $(<0.05)$. The table above shows that the loading of each indicator has fulfilled the convergent validity requirements, which is above 0.70 and is significant with a p-value below 0.05 . In addition, all indicators have low cross loading to other latent variables so that it shows good discriminant validity, except for indicators Mana1 (0.646), Mana5 (0.658), Mana6 (0.626), Tek3 (0.696), Tech5 (0.619), Manu1 (0.634), Manu2 (0.689), Manu6 (0.680), and PK5 (0.658), these indicators do not meet the convergent validity. Against these indicators will be dropped/removed from the research model and analyzed the impact of the decision to remove these indicators on AVE and Composite Reliability.

Table- III: Discriminant Validity, AVE, Reliabiitas, Cornbach's Alpha

\begin{tabular}{|c|c|c|c|c|}
\hline Variable & $\begin{array}{c}\text { SQRT } \\
\text { AVE }\end{array}$ & AVE & $\begin{array}{c}\text { Composite } \\
\text { Reliability }\end{array}$ & $\begin{array}{c}\text { Cornbach's } \\
\text { Alpha }\end{array}$ \\
\hline $\begin{array}{c}\text { Management } \\
\text { Safety } \\
\text { Interventions }\end{array}$ & 0.787 & $\begin{array}{c}0.62 \\
0\end{array}$ & 0830 & 0.793 \\
\hline $\begin{array}{c}\text { Technical } \\
\text { Safety } \\
\text { Interventions }\end{array}$ & 0.797 & $\begin{array}{c}0.63 \\
5\end{array}$ & 0874 & 0.807 \\
\hline $\begin{array}{c}\text { Human } \\
\text { Safety } \\
\text { Interventions }\end{array}$ & 0.808 & $\begin{array}{c}0.65 \\
3\end{array}$ & 0850 & 0.734 \\
\hline $\begin{array}{c}\text { Safety } \\
\text { Behavior }\end{array}$ & 0.912 & 0831 & 0.961 & 0.948 \\
\hline
\end{tabular}

Source: Data Processing Results, 2018

From the table above it can be seen that AVE from management safety interventions $=(0.620)$, technical safety interventions $=(0.635)$, human safety interventions $=(0.653)$, safety behavior $=(0.831)$. According to (Campbell and Fiske 1959) in [7], the average variance extracted ( AVE ) value must be greater than 0.5 . It shows that the value of management safety intervention is greater than $0.5(0.620$ $<0.5$ ), the value of technical safety intervention is greater than $0.5(0.635>0.5)$, the value of human safety intervention is greater than $0.5(0.653<0.5)$, the value of safety behavior is greater than $0.5(0.831>0.5)$. So it can be concluded that the AVE value of the variable above meets the discriminant validity criteria, and composite reliability meets the reliability requirements.

\section{B. Evaluation of Inner Models}

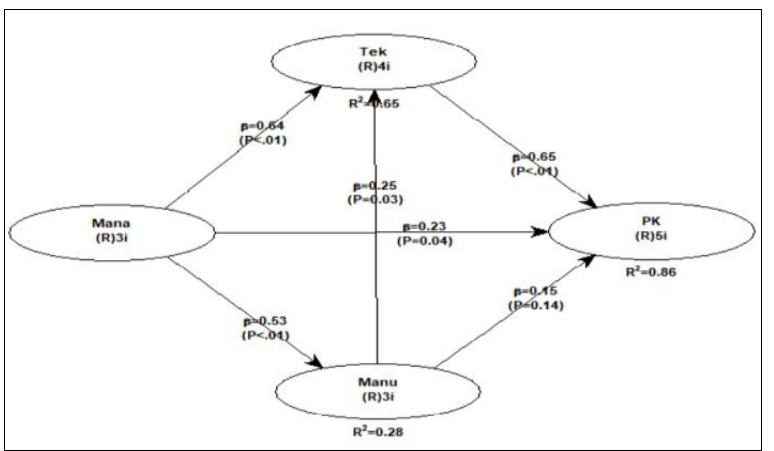

Fig. 2. Display the SEM analysis performance 
Source: Data Processing Results, 2018

Table- IV: Model Fit and Quality Indices

\begin{tabular}{|l|l|l|l|l|}
\hline No & Criteria & Value & Criteria & Information \\
\hline 1 & $\begin{array}{l}\text { Average Path } \\
\text { Coefficient } \\
\text { (APC) }\end{array}$ & 0.408 & $\mathrm{P}<0.001$ & Fit \\
\hline 2 & $\begin{array}{l}\text { Average } \\
\text { R-squared (A } \\
\text { RS) }\end{array}$ & 0.598 & $\mathrm{P}<0.001$ & Fit \\
\hline 3 & $\begin{array}{l}\text { Average } \\
\text { Adjusted } \\
\text { R-squared (A } \\
\text { ARS) }\end{array}$ & 0.585 & $\mathrm{P}<0.001$ & Fit \\
\hline 4 & $\begin{array}{l}\text { Average } \\
\text { Block }\end{array}$ & 1,918 & $\begin{array}{l}\text { value is } \leq \\
\text { VIF (AVIF) } \\
\text { if reasible if }\end{array}$ & Fit \\
& $\begin{array}{l}\text { feas } \\
\leq 3.3\end{array}$ & \\
\hline
\end{tabular}

Source: Data Processing Results, 2018

From the above table, it appears that the average path coefficient (Average Path Coefficient, APC $=0.408$ ) with a P-value $<0.001$, can be interpreted that the research model Fit. The average R2 (ARS) = (0598), which means that all of the exogenous variables have a contribution of $59.8 \%$ to the value of Conduct Safety (Safety Behavior). Average Block IF $\quad($ AVIF $)=1,918$ $<3.3$ which means ideal and Fit. GoF 0.640> 0.36, which means that the research model meets the Goen TenFenf (GoF) compatibility test.

Table- V: Hypothesis Results

\begin{tabular}{|c|c|c|c|c|c|}
\hline $\begin{array}{c}\text { Hypot } \\
\text { hesis }\end{array}$ & Path & $\begin{array}{c}\text { Coeffic } \\
\text { ients }\end{array}$ & $\begin{array}{c}\text { P } \\
\text { value }\end{array}$ & $\begin{array}{c}\text { Effect } \\
\text { size }(\mathrm{E} \\
\text { S) }\end{array}$ & Results \\
\hline H1 & $\begin{array}{c}\text { Mana } \rightarrow \cdot \text { Tec } \\
\text { h }\end{array}$ & 0.64 & 0.01 & 0.501 & Take effect \\
\hline H2 & $\begin{array}{c}\text { Mana } \rightarrow \cdot \text { Ma } \\
\text { nu }\end{array}$ & 0.53 & 0.01 & 0.285 & Take effect \\
\hline H3 & Where $\rightarrow \cdot$ PK & 0.23 & 0.04 & 0.182 & Take effect \\
\hline H4 & $\begin{array}{c}\text { Manu } \rightarrow \cdot \text { Tec } \\
\text { h }\end{array}$ & 0.25 & 0.03 & 0.148 & Take effect \\
\hline H5 & Manu $\rightarrow \cdot$ PK & 0.14 & 0.13 & 0.092 & No effect \\
\hline H6 & Tech $\rightarrow \cdot$ PK & 0.65 & 0.01 & 0.586 & Take effect \\
\hline
\end{tabular}

Source: Data Processing Results, 2018

Based on the H1 hypothesis test results above, it appears that the P-value $<0.01$ (Ho rejected). It can be concluded that there is a significant influence between management safety interventions on technical safety interventions. The magnitude of the effect of management safety interventions on technical safety interventions is $50.1 \%$. This means that the better the management of safety interventions, the better the technical safety interventions, the better the prevention of workplace accidents, the better the alertness to dealing with emergencies. This study is in line with the results of research by [2], which shows the positive influence of management safety interventions on technical safety interventions.

Based on the $\mathrm{H} 2$ hypothesis test results above, it appears that the P-value $<0.01$ (Ho has rejected). It can be concluded that there is a significant influence between management safety interventions and human safety interventions. The magnitude of the effect of management safety interventions on human safety interventions is $28.5 \%$. This means that the better the management of safety interventions, the better human safety interventions, the better the prevention of workplace accidents, the better the workplace safety counseling for new workers. This research is in line with the results of [2] research, which shows the positive influence of management safety interventions on human safety interventions.

Based on the results of the H3 hypothesis test above, it appears that the P-value $<0.01$ (Ho rejected). It can be concluded that there is a significant influence between safety management interventions and safety behavior. The magnitude of the effect of management safety interventions on safety behavior was $18.2 \%$. This means that the better the management of safety interventions, the better the safety behavior, namely the better prevention of work safety, the better the group cooperation in work safety. This study is not in line with the study of [2] showing that there is no effect on management safety interventions on safety behavior.

Based on the results of the $\mathrm{H} 4$ hypothesis test above, it appears that the P-value $<0.01$ (Ho rejected). It can be concluded that there is a significant influence between human safety interventions and technical safety interventions. The magnitude of the effect of human safety interventions on technical safety interventions amounted to $14.8 \%$. This means that the better the human safety intervention, the better the technical safety intervention, the better the work safety counseling for new workers, the better the alertness to facing an emergency. This study is in line with research by [2], which shows the positive influence of human safety interventions on technical safety interventions. Based on the results of the $\mathrm{H} 5$ hypothesis test above, it can be seen that the P-value of $0.134>0.05$ (Ho is accepted). It can be concluded that there is no effect on human safety interventions on safety behavior. Which can be interpreted that there are other variables that influence human safety interventions on safety behavior. This study is in line with research by [2]; human safety interventions do not influence safety behavior. Based on the results of the $\mathrm{H} 6$ hypothesis test above, it appears that the $\mathrm{P}$-value $<0.01$ (Ho is rejected). It can be concluded that there is a significant influence between technical safety interventions and safety behavior. The magnitude of the effect of technical safety interventions on safety behavior was $58.6 \%$. This means that the better the technical safety intervention, the better the safety behavior, that is, the better the alertness in dealing with emergency situations, the better the group cooperation in work safety.

This study is in line with previous studies from [2], which show that technical safety interventions have a positive effect on safety behavior.

Table-VI: R Square and Q Square

\begin{tabular}{|c|c|c|}
\hline & $\begin{array}{c}\mathrm{R} \\
\text { Square }\end{array}$ & $\begin{array}{c}\mathrm{Q} \\
\text { Square }\end{array}$ \\
\hline Tech & 0.649 & 0.648 \\
\hline Manu & 0.285 & 0.295 \\
\hline PK & 0.859 & 0.853 \\
\hline
\end{tabular}

Source: Data Processing Results, 2018

(C) Copyright: All rights reserved.
Published By:

Blue Eyes Intelligence Engineering \& Sciences Publication

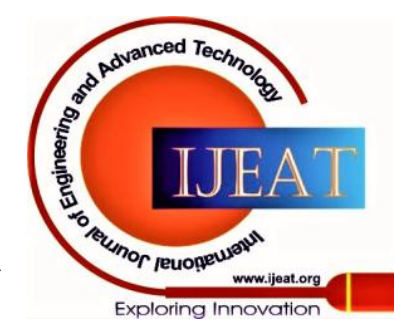

DOI: 10.35940/ijeat.B2885.089620

Journal Website: www.ijeat.org 
According to [6], Q- Squared (also called Stoner- Geisser coefficient) is a nonparametric measure obtained through blindfolding algorithm. Q-squared is used to assess the predictive validity or relevance of a set of predictor latent variables on the criterion variable. Q-squared is analogous to R-squared but can only be obtained through resampling. Q-squared can be negative, while $\mathrm{R}$-squared is always positive. Models with predictive validity must have Q-squared greater than zero. The estimation results of this research model show the good predictive validity of $0.648,0.295$, and 0.853 .

\section{CONCLUSION AND SUGGESTIONS}

Based on the results of research conducted at PT.Esa Bumindo can be concluded that management safety interventions affect technical safety interventions, meaning that the better the management safety interventions, the better the technical safety interventions. Management safety interventions affect human safety interventions, meaning that the better the safety management interventions, the better the human safety interventions. Management safety interventions directly influence safety behavior, meaning that the better the safety management intervention, the better the safety behavior. Human safety interventions affect technical safety interventions, meaning that the better the human safety interventions, the better the technical safety interventions. Human safety interventions have no significant effect on safety behavior. Technical safety interventions affect safety behavior, meaning that the better the technical safety intervention, the better the safety behavior.

Based on the results of data collection through a questionnaire distributed to respondents, data can be obtained that several indicators show low numbers. Therefore it is recommended to PT. Esa Bumindo to do things - one of which is the management of safety interventions on technical safety interventions should the company be able to increase interaction between workers and management so that the availability of safety equipment for employees. In management safety interventions on human safety interventions, companies should be able to increase interaction between workers and management so that the dissemination of work safety is conveyed. In management safety interventions on safety behavior, the company should be able to increase interaction between workers and management in order to create individual safety awareness. In human safety interventions on technical safety interventions, the company should be able to improve work safety socialization with the availability of work safety equipment for employees. In human safety, intervention does not affect safety behavior; therefore, for further researchers so that the variable is examined again. In technical safety interventions on safety behavior, it is suggested that companies can increase the availability of work safety equipment to create individual safety awareness.

\section{REFERENCES}

1. M. Khayam, "Peluang Pengembangan Industri Kimia Nasional Terbuka Lebar," 2016. [Online]. Available: http://www.kemenperin.go.id/artikel/15802/Peluang-Pengembangan-I ndustri-Kimia-Nasional-Terbuka-Lebar.

2. B. H. Zaira, M. M., \& Hadikusumo, "Structural equation model of integrated safety intervention practices affecting the safety behavior of workers in the construction industry," Saf. Sci., pp. 124-135, 2017.

3. Corcoles et al., "Leadership and employees perceived safety behaviours in a nuclear power plant: A structural equation modeling," J. Saf. Sci., vol. 49, no. 2011, pp. 1118-1129, 2011.

4. H. Huang, "Metode Penelitian Kuantitatif," globalstatistik, 2016. [Online]. Available:

http://www.globalstatistik.com/metode-penelitian-kuantitatif/.

[Accessed: 10-Jul-2018].

5. R. Sekaran, and Uma, Bougie, Research Method for Business, 6th ed. United Kingdom: John Wiley \& Son Ltd, 2015.

6. D. D. Sholihin, Ph. D, M., \& Ratmono, Analisis SEM-PLS dengan WarpPLS 3.0. Yogyakarta: C.V Andi Offset, 2013.

7. H. Ghozali, I., \& Latan, PARTIAL LEAST SQUARES, konsep, teknik dan Applikasi menggunakan Program SmartPLS 3.0 edisi 2. Semarang: Badan Penerbit Universitas Diponegoro Semarang, 2015.

8. Badan Pusat 2016 https://www.bps.go.id/website/pdf_publikasi/PerkembanganIndeks-P roduksi-Industri-Manufaktur-2014-2016--.pdf. Diperoleh tanggal 6 Mei

9. 2018. Dari http://www.bps.go.id.

10. Jogiyanto, \& W, A. (2009). Konsep \& Aplikasi PLS (Partial List Square) untuk Penelitian Empiris. Yogyakarta: BPFE.

11. Kock, N. (2015). Common Method bias in PLS-SEM: A ful Collinearity. International Journal of e-collaboration, 1-10.

\section{AUTHORS PROFILE}

Asep Abdurahman Tsani was born in Tangerang on January 3, 1996. The author completed his undergraduate education at Bina Nusantara University in Management in 2018.

Jeremy Rizky Marchziany was born in the city of Sukabumi on March 15, 1995. The author completed his undergraduate education at Bina Nusantara University in Management in 2018.

Yudhistira Dwi Hapsara was born in the city of Tangerang on May 9, 1995. The author completed his undergraduate education at Bina Nusantara University in Management in 2018.

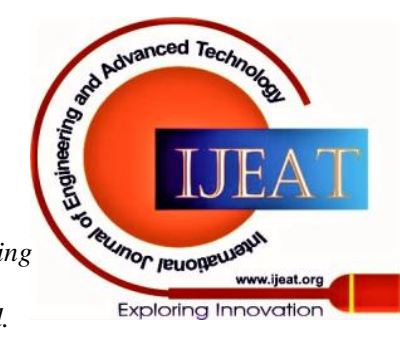

